\title{
INDUSTRIAL-AREA STREET TREES IN PORTLAND, OREGON
}

\author{
by Joseph Poracsky ${ }^{1}$ and Mark Scott ${ }^{2}$
}

\begin{abstract}
Industrial-area trees have, with few exceptions, been neglected by the research community as well as by urban forestry management programs. A recent project in Portland, Oregon, provides both some data and a program model that easily could be replicated in other communities. An inventory of the Northwest Industrial Neighborhood Association (NINA) district identified 966 street trees and 1,140 unplanted/potential street tree sites, for a stocking level of $46 \%$. While this figure is low relative to most other segments of the urban forest, it was received optimistically because it was higher than had been expected for an industrial area and it demonstrated a great deal of potential for expanding the urban forest through additional plantings. Diversity data indicated only 17 genera were represented, identified two genera (Acer and Prunus) that were overplanted, and provided guidance on which genera could be added to increase diversity. NINA officials have formed a partnership with other local urban forestry interests and are using the data to undertake a 10 year planting program for the district.
\end{abstract}

Key Words. Street tree inventory; industrial neighborhood; urban forest partnerships; cooperative planting program.

A wide range of literature concerns urban forest inventory (e.g., Smiley and Baker 1988; McBride and Nowak 1989; Jaenson et al. 1992; Bloniarz and Ryan 1996; Miller 1997). That street tree inventories figure prominently in this literature is not surprising because a major portion of urban forest management involves street trees. A review of inventory data quickly leads to the conclusion that there is great variety in the density, ages, and species composition of street tree populations (e.g., Schoon 1993; Lesser 1996).

While a number of physical and cultural factors combine to produce street tree variety, one important factor is land use. Significant differences in species mix, density, and tree condition may be found not only between cities but between different land use areas within a single city. Concern with street trees has only infrequently focused on the attributes of street trees relative to adjacent land uses (e.g.,
Rowntree 1984; Sanders and Stevens 1984; Nowak 1994) and, as a result, we have only limited empirical information concerning the relationship between street trees and land use.

Data are particularly poor with regard to industrial land, making industrial areas the least-studied portion of the urban forest. Both experience and common sense tells us that an industrial area is likely to be almost entirely hardscape and that the combination of large building footprints, extensive paved areas for parking and storage, and a dense transportation net of roads and rail lines means that little space is available for trees. But the simple lack of space is only part of the story.

Commonly, the planting space available in industrial areas is not hospitable to tree growth. The preponderance of concrete and asphalt serves to hold the summer heat, artificially raising both air and soil temperatures and leading to desiccated soils. The limited planting space provides only minimal exposed soil surface for the infiltration of precipitation and the aeration of soils. The soils themselves are often heavily disturbed and lack the vertical zonation representative of a healthy soil profile. Poor soil condition is intensified by the traffic of large trucks, creating soil compaction problems and raising the likelihood of physical damage to trunks and branches. Vehicle traffic also produces emissions that combine with industrial emissions to create air quality that can be detrimental to tree growth and survival.

Overall, the term "industrial area" is more likely to conjure up dreary images of weathered buildings, smoke-filled air, and noisy equipment, than images of trees and green landscape. Perhaps this image is what has tended to deflect urban forestry interest away from industrial areas. Whatever the reason for this neglect, it would appear that perhaps we are missing an opportunity to improve the urban forest. Observation has shown that trees can survive and even thrive in industrial areas. It is clear that the numerous negative site conditions that tend to occur in industrial areas are not absolute barriers to tree 
growth but simply a special (albeit extreme) case of the conditions that trees face in virtually every part of the urban forest. As in other environments of urban areas, the tree-growing constraints may be overcome by intelligent selection of species, care in planting, and conscientious maintenance.

\section{PORTLAND'S NINA DISTRICT}

As Oregon's only metropolitan area, Portland contains an array of industrial districts that serve the needs of the city and region. One of the most distinctive is the Northwest Industrial Neighborhood Association (NINA) district. NINA was created by city ordinance as an industrial sanctuary in 1974 and was incorporated on February 4, 1976 (Martin 1996). The district operates as one of nearly 100 neighborhood associations formally recognized by the city.

Located in the northwestern corner of the city, NINA is bounded by the Willamette River on the east, Nicolai Street on the south, St. Helens Road and the foot of the West Hills on the west, and the St. Johns Bridge on the north. The area occupies a long, narrow bench of floodplain between the river and the West Hills, which rise sharply to more than $300 \mathrm{~m}(1,000 \mathrm{ft})$ above the floodplain. Much of the land is former wetland, occupying the site of the 1905 Lewis and Clark Exposition, and filled following the Exposition to create land for port, rail, and industrial facilities (MacColl 1976).

The district encompasses 657 ha $(1,621 \mathrm{ac})$ of privately owned land and includes 555 employers and 20,300 employees (ONA and CUS 1993). The NINA area is characterized by wide streets and low, sprawling buildings housing light fabrication and warehouse facilities. There are no residences or lodging in the district, and several railroad lines dissect the area. A large percentage of the district is paved, and long stretches of streetscape are given over to loading docks, building edges, and fences around storage areas. Vehicle traffic during working hours is moderate-to-heavy and has a high proportion of large trucks.

Running the length of the district is U.S. Highway 30 , a major road leading into Portland from the north and connecting the city to other communities on the Oregon side of the Columbia River. The presence of this highway makes the NINA district a ma- jor gateway into northwest Portland, and its appearance is important in creating an initial impression of the city to visitors. Concern about improving the aesthetics of the district led Chuck Martin, the visionary president of the NINA board, to press for instituting a long-term tree planting program. Paralleling similar efforts in other cities (e.g., Thamen 1990; Newland 1995), the objective is to enhance the visual character of the area, making the district a more pleasant place for its employees to work and for the public to pass through.

The program's goal is to plant 100 trees a year for 10 years. To achieve this goal, a partnership was developed that includes 5 major groups:

1. Portland State University performs inventory work, surveying existing street trees and identifying planting opportunities.

2. The city's Urban Forestry Program assists in verifying planting sites and streamlining the planting permit process.

3. Friends of Trees, a local nonprofit tree planting organization with years of experience, coordinates the actual tree plantings.

4. Individual property owners cost-share with NINA on the purchase, planting, and maintenance of trees.

5. NINA performs overall project coordination, working with individual property owners, acquiring planting stock, and ensuring adequate watering and maintenance for 2 years after planting.

The details of each partner's role were worked out during several planning meetings.

\section{THE INVENTORY}

The project area was restricted to the most densely developed portion of the district-that portion south of the Kittridge Avenue overpass. This area encompasses some 30 streets, including heavily traveled main thoroughfares such as Front Avenue, Yeon Avenue (U.S. Highway 30), St. Helens Road, Nicolai Avenue, and many smaller connecting streets. Deadend streets within the study area boundaries were not included.

Data were collected between early April and midMay 1996. In all, approximately $14 \mathrm{~km}$ (9 mi) of streets between the Fremont Bridge and the Kittridge 
Avenue overpass were inventoried. The inventory was performed by walking all the streets in the project area, recording locations of existing trees, identifying and recording planting opportunity sites, plotting the information on a map, and summarizing the map data.

A planting opportunity is defined as any unplanted streetside location that meets 3 criteria.

1. The site allows inter-tree spacing of about $9 \mathrm{~m}$ (30 ft), a distance that is used as a general city standard (Urban Forestry Program 1994), recognizing that actual spacing will vary depending on the species.

2. The site conforms to City of Portland guidelines for appropriate distances from corners, driveways, hydrants, utility poles, signs, etc. (Urban Forestry Program 1994).

3. The site has no constraint that precludes healthy tree growth and development (e.g., insufficient sidewalk width to accommodate a tree, physical barriers such as walls or fences, or inadequate clearance adjacent to traffic).

No attempt was made in the inventory to identify an appropriate species to plant in an individual site; this decision was left to be made jointly by NINA, the property owners, and Urban Forestry staff, on a siteby-site basis.

\section{The Inventory Map}

The inventory data were recorded on a $90 \times 190 \mathrm{~cm}$ $(36 \times 75 \mathrm{in}$.) map at a scale of $1 \mathrm{~cm}=24 \mathrm{~m}$ ( 1 in. $=$ $200 \mathrm{ft}$ ), which allows symbols and notations that are large enough to be legible without producing visual clutter. At this scale, streets are about 0.6 to $1.6 \mathrm{~cm}$ ( 0.25 to $0.63 \mathrm{in}$.) wide. Though it was proposed to prepare the map digitally in a GIS-compatible format, NINA officials opted for a hand-drawn map.

Figure 1 is a reproduction of a portion of the map (Poracsky and Scott 1996), illustrating the 4 major symbols.

1. A filled circle represents the location of an existing tree. Next to each filled circle is a 3-part notation indicating the size and species of the tree, with size indicated as diameter (in inches and height (in feet). For example, the notation "14/25/cherry" indicates a cherry tree 14 in. (36 $\mathrm{cm}$ ) in diameter and $25 \mathrm{ft}(7.5 \mathrm{~m})$ tall.
2. An open circle represents a vacant tree site, defined as a planting opportunity site which already has a cut-out in the sidewalk. Such a site would require only that a hole be dug in order to plant a tree.

3. An open diamond represents a potential tree site, consisting of a planting opportunity site that does not have a cut-out. To plant in such a site, it would be necessary to both make a cutout in the sidewalk and dig a hole, thus increasing the expense of planting.

4. A toothlike " $V$ " represents a driveway, vehicle access road, or loading dock. These features restrict the planting of trees close by because of potential soil compaction resulting from traffic, the potential for trees blocking the view of oncoming traffic, and the potential for physical injury to the tree.

Also included on the map are notations about the presence of fences or overhead wires, along with the size of planting strip and the presence of any private property plantings that are readily visible from the street. Overall, the combination of information on the map provides the basis for locating the street tree planting opportunities throughout the study area, defining the list of trees potentially appropriate for each site, and conceptualizing the outcome within the spatial pattern of the existing trees. The map is also useful in indicating constraints and in identifying sites that would be more expensive to plant because of the need for a cutout.

Final approval in siting and selecting street trees in the city resides with the Urban Forestry Program (City of Portland 1987) and plantings must be in conformance with published guidelines (Urban Forestry Program 1994). Three key checks in the project procedure ensured that the integrity of the city guidelines were maintained. First, before beginning the inventory, an on-site meeting was held with a city tree inspector to review planting guidelines and the unique problems of tree siting in an industrial area. Second, following completion of about $20 \%$ of the inventory work, another on-site meeting was held with the inspector to ensure that the siting decisions incorporated in the data conformed to city planting guidelines. When the full map was completed, NINA used it as a guide for selecting planting 


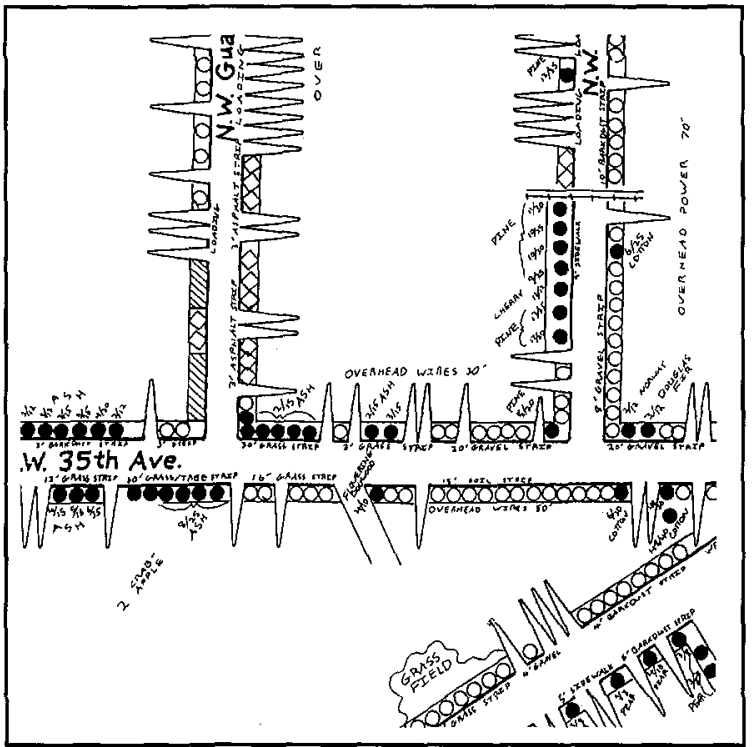

Figure 1. Section of the inventory map reduced to about one-half the original size.

sites and identifying property owners to enlist in the program. At this point the third check occurred, when NINA had to obtain formal Urban Forestry Program approval for planting individual sites and species.

\section{Existing Trees}

Because species identification and sizes of existing trees were not requirements of the inventory, no formal keying of species or actual size measurement was performed. However, because the data were easy to capture, the inventory recorded tree genera, visually estimated heights and diameters, and noted topping occurrences.

The genera data summarized in Table 1 provide a useful indicator of diversity. A total of 966 street trees were recorded in the inventory, representing 17 genera; 5 trees were not identified. An often-stated guideline in urban forestry cautions "that no genus should account for more than $10 \%$ and no species for more than $5 \%$ of the total" (Kielbaso 1989). In the case of NINA, 2 genera exceeded $10 \%$ of the total: Acer (52.1\%) and Platanus (10.7\%). Together these 2 genera constituted $62.8 \%$ of the street tree plantings. Four more genera occurred in large numbers (i.e., exceeded 5\% of the total): Prunus (7.7\%), Fraxinus (6.6\%), Pinus (6\%), and Quercus (5.7\%.)
Thus, a total of $88.8 \%$ of the trees in the district are accounted for by just 6 genera.

The Acer and Prunus genera are both large groups, between them including more than 500 species (Jacobson 1996). To better understand their composition within the inventory, the data for these 2 genera are further broken out in Table 2. In the case of both genera, there are distinct patterns. Acer is heavily dominated by Norway (A. platanoides) and red maple (A. mubra), together accounting for all but 7 of the 503 Acer specimens in the inventory. In addition, their $32.4 \%$ and $18.9 \%$ representation within the inventory means that each of these 2 species is found in larger numbers than the next most-frequent genus, Platanus. Within the genus Prumus, the majority of the specimens are plum cultivars, which outnumber cherry cultivars by more than 2 to 1 .

NINA's street trees tend to be small: Only 105 of the 966 street trees (10.9\%) have a diameter of $25 \mathrm{~cm}$ (10 in.) or larger (Table 3). Five of the 17 genera found in the inventory do not even occur at sizes of $25 \mathrm{~cm}$ or larger: Platanus, Pseudostuga, Pyrus, Robinia, and Ilex. Trees from all 5 of these genera can easily

Table 1. The inventory identified a total of 966 street trees representing 17 genera.

\begin{tabular}{lrc}
\hline Genus & Count & $\begin{array}{l}\text { Percentage } \\
\text { of total }\end{array}$ \\
\hline Acer & 503 & 52.1 \\
Platanus & 103 & 10.7 \\
Prunus & 74 & 7.7 \\
Fraxinus & 64 & 6.6 \\
Pinus & 58 & 6.0 \\
Quercus & 55 & 5.7 \\
Pyrus & 24 & 2.5 \\
Betula & 19 & 2.0 \\
Thuja & 19 & 2.0 \\
Pseudostuga & 11 & 1.1 \\
Alnus & 9 & 0.9 \\
Juglans & 6 & 0.6 \\
Liquidambar & 4 & 0.4 \\
Cornus & 4 & 0.4 \\
Populus & 4 & 0.4 \\
Robinia & 2 & 0.2 \\
Ilex & 2 & 0.2 \\
Unknown & 5 & 0.5 \\
Total & $\mathbf{9 6 6}$ & $\mathbf{1 0 0}$ \\
\hline
\end{tabular}


Table 2. Detail of the Acer and Prunus genera in the inventory.

\begin{tabular}{llrl}
\hline Genus & Species & Count & $\begin{array}{c}\text { Percentage } \\
\text { of all trees }\end{array}$ \\
\hline Acer & Norway maple & 313 & 32.4 \\
& Red maple & 183 & 18.9 \\
& Japanese maple & 4 & 0.4 \\
& Bigleaf maple & 3 & 0.3 \\
Prunus & Plum & 53 & 5.5 \\
& Cherry & 21 & 2.2 \\
Total & & $\mathbf{5 7 7}$ & $\mathbf{5 9 . 7}$ \\
\hline
\end{tabular}

attain a $25 \mathrm{~cm}$ or larger diameter, making the absence of specimens at this size particularly telling of the young age of the population. The three largest trees are a 120-cm (48-in.) Populus trichocarpa (black cottonwood), a 75-cm (30-in.) Cornus nuttallii (western dogwood), and a 70-cm (27-in.) Acer macrophyllum (bigleaf or Oregon maple.)

Even though they constitute only $6 \%$ of the total inventory, members of the genus Pinus have the greatest number of large diameter trees, probably reflecting the generally rapid growth rate of individuals in this genus. For those trees under $25 \mathrm{~cm}$ in diameter, the mean size is estimated to be about 15 to $18 \mathrm{~cm}$ ( 6 to $7 \mathrm{in}$ ), but all diameters throughout the range from 3 to $23 \mathrm{~cm}$ ( 1 to $9 \mathrm{in}$.) were represented by more than just a few specimens, again reflecting the generally young age of the population.

In general, the trees were judged to be in good to excellent condition. The most common undesirable condition observed was physical injury, particularly bark scarring caused by vehicles. Topping, a serious problem in many Portland residential areas, was observed on only 24 trees and was not judged to be a major problem. This surprisingly low number is probably attributable to the young age of most of the trees, portending that topping may become a problem as the population matures. No other widespread adverse health conditions were observed, although it is possible that insects or diseases may have been present and simply not yet visible during the early part of the growing season when the inventory was performed.
Table 3. Street trees of $25 \mathrm{~cm}$ (10 in.) and larger diameter.

\begin{tabular}{lcccl}
\hline & \multicolumn{4}{c}{ Dbh, cm (in.) } \\
\cline { 2 - 5 } Genus & $25-32$ & $33-40$ & $41-63$ & $64-122$ \\
\hline Acer & 10 & 3 & 2 & 1 \\
Prunus & 8 & 6 & 0 & 0 \\
Fraxinus & 1 & 4 & 2 & 0 \\
Pinus & 11 & 13 & 14 & 0 \\
Quercus & 2 & 6 & 0 & 0 \\
Betula & 6 & 0 & 0 & 0 \\
Thuja & 0 & 2 & 0 & 0 \\
Alnus & 4 & 0 & 0 & 0 \\
Juglans & 5 & 0 & 0 & 0 \\
Liquidambar & 1 & 0 & 0 & 0 \\
Cornus & 0 & 2 & 0 & 1 \\
Populus & 0 & 0 & 0 & 1 \\
Total & $\mathbf{4 8}$ & $\mathbf{3 6}$ & $\mathbf{1 8}$ & $\mathbf{3}$ \\
\hline
\end{tabular}

\section{Planting Opportunities}

The entire inventory area includes 761 vacant tree sites and 379 potential tree sites, for a total of 1,140 planting opportunities. Adding the planting opportunities and the existing tree sites yields a total of 2,106 street trees that the area could support. Dividing the number of existing trees by the full-stocking figure (i.e., 966/2,106), yields a current stocking level of $46 \%$. A review of the literature did not uncover stocking-level figures for other industrial areas, so an evaluation of stocking level cannot be made on the basis of a direct comparison with other similar land uses. However, to provide some context, reference can be made to two other recent inventories in the Portland metropolitan area. The Irvington neighborhood of Northeast Portland has a $72 \%$ stocking level (Poracsky and Waggoner 1994), and the community of Forest Grove-about $32 \mathrm{~km}$ (20 mi) west of Portland-has a $62 \%$ stocking level (Waggoner 1998). A direct comparison between these figures and the NINA figure is not possible because of the different character of the land uses involved: Irvington is an upper-middle-class residential area with a reputation for being well-treed, and Forest Grove is a largely residential community of about 12,000 people. Given the differences in planting density that one would expect between a residential area and an industrial area, a 
direct comparison of this type would not be reliable. Nonetheless, this comparison is useful in helping relate the results to the regional urban forest context. In this regard, the $46 \%$ stocking level for the NINA area, while small compared to $62 \%$ and $72 \%$, is higher than what most people might have estimated for a heavily developed industrial area.

\section{RECOMMENDATIONS}

Based on the statistical data and other observations collected during the inventory, a number of recommendations were made to assist NINA in developing a strategy to reach its street tree goals. Four will be discussed, since they are particularly relevant to the general issue of industrial area plantings.

First, planting efforts should initially be focused on the most heavily traveled streets. The logic here is that the more people who observe the visual enhancement of the district, the greater the impact of the plantings. In turn, visibly successful plantings are likely to help build support for continuing and expanding the program in the future. Less heavily traveled streets can be planted in later years of the program.

Second, the varieties of trees being planted should be diversified. Given that nearly $89 \%$ of the existing trees come from only 7 genera, there is adequate opportunity to consider different varieties for the new plantings. Actual species selection depends on individual site characteristics but, even within the severe habitat constraints of an industrial area, there are possibilities for much more variety than currently exists. The more diversity, the greater the potential visual interest that the trees can create and, so long as durable species are selected, the greater variety may help ensure higher survival rates and help protect against species-specific pests.

Third, special physical protection needs to be provided for newly planted trees. Industrial districts are extremely vehicle-oriented and, in such areas, drivers are not accustomed to having to think about trees and the physical damage their vehicles might inflict. Many of the planting opportunities identified are far enough removed from vehicles that there will be little opportunity for tree damage to occur. However, other planting sites will put trees in places where vehicles in the district have not had to deal with them in the past and where drivers might over- look their presence. In many cases, it would be useful to consider installing tree guards or physical barriers such as curbs, low fences, or railings. In other instances the addition of brightly colored flags on or around a tree would increase its visibility and draw a driver's attention to its presence. These markers should be needed for only a few years, until the tree has gained size, and perhaps only in the leaf-off period, when trees would be less visible in the gray, rainy weather that characterizes more than half of Portland's year.

Fourth, special attention needs to be paid to maintenance. To combat the desiccating effect of large pavement areas, regular watering during Portland's typically dry summer is a necessity. A regular cycle of pruning and crown lifting of trees will reduce the likelihood of "vehicular pruning" occurring and creating damage that is both unattractive for the eye and unhealthy for the tree.

\section{DISCUSSION}

NINA is undertaking an innovative and positive program that will improve both the district and the larger community. The program has an ambitious but realistic set of goals, a clear and simple strategy, and is being implemented in a cooperative fashion. NINA has taken the time to include a range of interested constituencies as partners and to draw on a variety of existing community resources for assistance. The partnership was an essential element to this project because no one group would have been successful in acting alone. The success of the partnership was the result of four factors.

1. Willingness to participate on the part of the individual businesses was essential. Because the project was initiated by NINA_-an organization of business people - and NINA did the contact work, buy-in by the business community was facilitated.

2. The work was divided into discrete parts (inventory, business contacts, permitting, planting, follow-up maintenance), ensuring that no one partner was overwhelmed with work.

3. The tasks and responsibilities were clearly defined, meaning that all partners clearly understood their roles and could concentrate on it. 
4. All partners felt a high degree of commitment to the project and followed through on their roles.

These partnerships are expected to continue as the program progresses, providing a nucleus of players capable of readily implementing the model in other industrial areas.

The planting of trees in an industrial area is an uncommon but far-sighted endeavor, and corresponds directly to several of the specific actions identified for industrial areas in Portland's Urban Forestry Management Plan (City of Portland 1995). The response of local property owners has been positive. The first year's planting was successful, and the second planting year is currently being planned.

The planting project will have a significant beneficial effect and will pay dividends for years to come. On the human environmental side, the longterm impacts will include enhanced aesthetics, a more pleasant working environment, improved employee morale (Kaplan 1993), and a more positive public image. Visitors entering the city through the NINA district will be met with a more welcoming gateway. These positive impacts may likely lead to increased competition between businesses to locate in such a desirable environment. Other benefits on the physical environmental side will also accrue. Heat-island effects will be ameliorated (McPherson 1994), runoff may be reduced (Walton 1998), and air quality may be improved (Nowak 1993).

The planting of a large number of trees in a short period of time brings up the issue of creating an even-aged stand, leading to concern about many trees dying at the same time. In commercial forestry, where many acres of the same species are planted, stand-age is a concern and, in fact, a goal--specifically to create an even-aged stand for harvesting. In urban areas, if only one or a very few species were being planted, producing an even-age stand might be a worry. However, so long as there are a variety of species involved, even-age does not result in even life expectancy. So long as diversity in plantings is adhered to, the issue of even-age is likely to be unimportant. It can be argued that the more serious concern in the urban forest is the premature death of individual trees due to environmental factors, human damage, or intentional removal.
While the benefits of street tree planting are likely to be particularly great in an industrial area, the cost associated with creating these benefits is low. Given the reduced number of planting opportunities available in an industrial area, a successful tree planting can be achieved by adding a relatively small number of trees. In the NINA case, for example, each 100 trees represents a nearly $5 \%$ increase in stocking level. The NINA project provides a model for action that is simple but powerful-and one that should be easy to replicate in other communities.

Thus exists a bit of a paradox in the interpretation of the stocking level figure. Relative to what had been anticipated to be found in an industrial area, $46 \%$ is a large number, but in absolute terms it is a small number and indicates a great deal of potential for planting and expansion of the urban forest. NINA has a goal of planting 100 trees a year for the next 10 years, for a total of 1,000 trees. The 1,140 planting opportunities that the inventory identified indicates that there is more than enough potential for NINA to achieve that goal.

Industrial-area plantings offer a rich opportunity for improving an overlooked segment of the urban forest. The data presented here offer a glimpse of the kinds of situations and opportunities found in one particular industrial area. It is hoped that as other studies are performed, we will develop an improved understanding of industrial area tree situations.

\section{LITERATURE CITED}

Bloniarz, D.V., and H.D.P. Ryan, III. 1996. The use of volunteer initiatives in conducting urban forest resource inventories. J. Arboric. 22:75-82.

City of Portland. 1987. Street tree and other public tree regulations. Chapter 20.40, City of Portland regulations, adopted by City Council March 31, 1987, Portland, OR. $12 \mathrm{pp}$.

City of Portland. 1995. Portland's urban forestry management plan. Ord. no. 168979, adopted by City Council June 28, 1995, Portland, OR. 98 pp. plus apps.

Jacobson, A.L. 1996. North American Landscape Trees. Ten Speed Press, Berkeley, CA. 722 pp.

Jaenson, R., N. Bassuk, S. Schwager, and D. Headley. 1992. A statistical method for the accurate and rapid sampling of urban street tree populations. J. Arboric. 18: 171-183.

Kaplan, R. 1993. Urban forestry and the workplace, pp 41-45. In Gobster, Paul H. (Ed.). Managing Urban 
and High-Use Recreation Settings. USDA Forest Service North Central Forest Experiment Station, Chicago, IL. $142 \mathrm{pp}$.

Kielbaso, J.J. 1989. City tree care programs: A status report, pp 35-46. In Moll, G., and S. Ebenreck (Eds.). Shading Our Cities. Island Press, Washington, DC.

Lesser, L.M. 1996. Street tree diversity and dbh in Southern California. J. Arboric. 22:180-186.

MacColl, E.K. 1976. The Shaping of a City: Business and Politics in Portland, Oregon 1885 to 1915. The Georgian Press, Portland, OR. 535 pp.

Martin, C.H. 1996. Personal communication with NINA president on May 29.

McBride, J.R., and D.J. Nowak. 1989. Urban park tree inventories. Arboric. J. 13:345-361.

McPherson, E.G. 1994. Cooling urban heat islands with sustainable landscapes, pp 151-171. In Platt, R.H., R.A. Rowntree, and P.C. Muick (Eds.). The Ecological City: Preserving and Restoring Urban Biodiversity. The University of Massachusetts Press, Amherst, MA.

Miller, R.W. 1997. Urban Forestry: Planning and Managing Urban Greenspaces. (2nd ed.) Prentice-Hall, Upper Saddle River, NJ. 502 pp.

Newland, K.T. 1995. Economic development strategy transforms landscape-Philadelphia's 26th Street gateway, pp 138-139--In Inside Urban Ecosystems; Proceedings, 7th National Urban Forestry Conference.

Nowak, D.J. 1993. Atmospheric carbon reduction by urban trees. J. Environ. Manage. 37:207-217.

Nowak, D.J. 1994. Urban forest structure: The state of Chicago's urban forest, pp 3-18. In McPherson, E.G., D.J. Nowak, and R.A. Rowntree (Eds.). Chicago's Urban Forest Ecosystem: Results of the Chicago Urban Forest Climate Project. USDA Forest Service Northeastern Forest Experiment Station, Radnor, PA.

ONA and CUS. 1993. Portland neighborhood information profiles. Official Neighborhood Association, City of Portland, and Center for Urban Studies, Portland State University, Portland, OR. 682 pp.

Poracsky, J., and M. Scott. 1996. Map at scale of $1 \mathrm{~cm}=24 \mathrm{~m}$ to accompany inventory of street trees in the Northwest Industrial Neighborhood Association (NINA) district of Portland, Oregon: Final report. Cartography Center, Portland State University, Portland, OR.
Poracsky, J., and L. Waggoner. 1994. Street trees in a residential Portland neighborhood. Unpublished paper, 52nd Annual Meeting, Oregon Academy of Science. 4 pp.

Rowntree, R.A. 1984. Forest canopy cover and land use in four eastern United States cities. Urb. Ecol. 8:55-67.

Sanders, R., and J.C. Stevens. 1984. Urban forest of Dayton, Ohio: A preliminary assessment. Urb. Ecol. 8:91-98.

Schoon, K.J. 1993. The Midwest urban tree index. J.Arboric. 19:230-237.

Smiley, E.T., and F.A. Baker. 1988. Options in street tree inventories. J. Arboric. 14:36-42.

Thaman, R.H., Jr. 1990. The meaning of the corporate landscape. Make Our Cities Safe for Trees, Proceedings, 4th Urban Forestry Conference. pp 4647.

Urban Forestry Program. 1994. Street trees planting and maintenance guidelines. Bureau of Parks and Recreation, Portland, OR. 3 pp.

Waggoner, L.L. 1998. Street trees in the urban forest: A case study of the city of Forest Grove, Oregon. Unpublished M.S. thesis. Geography Department, Portland State University, Portland, OR. 142 pp.

Walton, J.T. 1998. Stormwater-runoff reduction by urban trees in Austin, Texas, pp 82-85. In Kollin, Cheryl (Ed.). Proceedings, 8th National Urban Forestry Conference.

Acknowledgements. Completion of this project would not have been possible without the assistance, advice, and cooperation of Brian McNerney, Urban Forest Manager, City of Portland; Joe Hintz, Tree Inspector, City of Portland; Chuck Martin, former President, NINA; Clark Shankenberger, Project Coordinator, NINA; Richard Seidman, former Director, Friends of Trees; and Carolyn Perry, Office Coordinator, Geography Department, Portland State University.
${ }^{1}$ Professor and ${ }^{2}$ Graduate Student
Department of Geography
Portland State University
Portland, OR 97207-0751 
Résumé. Un inventaire du district du Northwest Industrial Neighborhood Association (NINA) à Portland a permis d'identifier 966 arbres de rues et 1140 sites potentiels de plantation. Alors que le résultat de $46 \%$ du taux d'occupation est considérablement inférieur à celui de deux autres secteurs non industriels du Portland métropolitain qui ont été inventoriés, il demeure malgré tout que taux a été jugé comme étonnamment élevé pour un secteur industriel. La diversité était faible avec seulement 17 genres présents. Localement, les données ont été utilisées pour planifier un programme de plantation de 10 ans pour le district du NINA. À une plus grande échelle, ces données fournissent une idée de la situation unique des possibilités et du potentiel de plantation d'arbres de rues dans les secteurs industriels.

Zusammenfassung. Eine Bestandsaufnahme der Nachbarschaftsvereinigung nordwestlicher Industriestandorte (NINA) mit Sitz in Portland identifizierte 966 Strassenbäume und zusätzlich 1140 mögliche Pflanzstandorte. Währent die resultierende Anwachsrate von $46 \%$ deutlich unter der von zwei nicht-industriellen An- lagen in der Metropole Portland lag, wird es doch für einen industriellen Standort als überraschend hoch angesehen. Die Artenvielfalt war gering mit nur 17 verwendeten Arten. Anhand dieser Daten wird nun für den NINA-Distrikt ein 10-Jahres Pflanzplan entwickelt. Auf höherer Ebene liefern die erhobenen Daten wichtige Informationen über die Besonnderheiten und Möglichkeiten von Strassenbäumen an industriellen Standorten.

Resumen. Un inventario de la Asociación Industrial de Vecinos del Noroeste (NINA), Distrito de Portland, identificó 966 árboles de la calle y 1,140 sitios apropiados de plantación. Mientras el nivel resultante del $46 \%$ en reserva, es dramáticamente más bajo que para dos inventarios del Portland Metropolitano no industrial, fue considerado sorprendentemente alto para un área industrial, La diversidad fue baja, con solamente 17 géneros presentes. Localmente, los datos han sido usados para planear un programa de plantación a 10 años para el distrito NINA. A gran escala, los datos proveen resultados únicos relacionados con árboles de la calle en áreas industriales. 